\title{
Where does blue water go in the semi-arid area of northern China under changing environments?
}

\author{
LILIANG REN, FEI YUAN, BIN YONG, SHANHU JIANG, XIAOLI YANG, \\ LUYAN GONG, MINGWEI MA, YI LIU \& HONGREN SHEN \\ State Key Laboratory of Hydrology-Water Resources and Hydraulic Engineering, College of Hydrology and Water \\ Resources, Hohai University, No. 1 Xikang Road, Nanjing, 210098, China \\ RLL@,hhu.edu.cn
}

\begin{abstract}
River flow regimes in the semi-arid region of northern China show a decreasing trend in terms of quantity. River runoff (i.e. blue water) reduction within the Laohahe catchment, the source area of the Liaohe River basin, manifests the aridity that exists widely in northern China. According to the water balance equation, during the past half-century, observed streamflow records in the Laohahe catchment show that blue water was re-directed to green water flow (i.e. evapotranspiration) over annual and decadal time scales, whereas precipitation did not vary much. Human activities and land-use/land-cover changes are the fundamental reasons for such runoff change. In the studied catchment, extensive land reclamation for agriculture, water withdrawal from streams, and abstraction from aquifers for irrigation are the direct and main causes leading to the decrease in observed blue water. These factors further demonstrate that a land-use decision is also a decision about water. Therefore, there is a need for an integrated modelling framework to intrinsically link climate, hydrological, and agricultural models with social and economic analyses.
\end{abstract}

Key words runoff; evapotranspiration; blue water; green water; land use and cover changes; water balance

\section{INTRODUCTION}

Runoff (i.e. blue water) change can arise from the variations of precipitation, infiltration, evapotranspiration processes, etc. Evapotranspiration is a function of energy, water availability, and near-surface atmospheric conditions (Gedney et al. 2006). Land-use and cover changes (LUCC) affect infiltration and evapotranspiration in many ways. Contemporary environmental changes can therefore positively (runoff increasing, Labat et al. 2004, Gedney, et al. 2006) or negatively (runoff decreasing, Ren et al. 2002, Wang et al. 2010) affect blue water. Worldwide continental runoff has increased throughout the 20th century (Labat et al. 2004) despite more intensive human water consumption (Shiklomanov 2000). However, this is not the case in northern China (Ren et al. 2002, Wang et al. 2010) where less and less water flows in streams or rivers, and therefore more and more water is contaminated. This affects all aspects of local human lives. This paper aims to investigate the quantitative effect of human activities on river runoff and to account for the driving forces leading to blue water reduction under climate change and variability.

China is affected by a monsoon climate with an uneven distribution of precipitation in different regions and time periods. From the late 1970s to the early 1980s, the East Asian monsoon pattern changed. The southern part of China became wetter and the northern part became drier. Currently, northern China suffers from severe water stress. The Science Implementation Plan of the cross-cutting Monsoon Asia Integrated Regional Study Project (Fu and Penning de Vries, 2007), in the framework of the Earth System Science Partnership, demonstrated that the semi-arid region is more vulnerable and problematic under global change. To solve the food shortage problem, large areas of land have been reclaimed as cultivated fields for agricultural production in northern China. The Laohahe catchment is a typical area in the context of global change, especially for the study of human effects on river runoff.

With less water in semi-arid regions, more water is needed for human living, production and ecology. Most irrigation water evaporates into the atmosphere after application to the soil, because the atmospheric demand for evaporation is higher in arid areas. From the 1950s through to the 2000 s, the Laohahe catchment has shown a clear tendency for the decrease of blue water, as both the correlation coefficients and regression slopes in Fig. 1 demonstrate. This implies that annual precipitation and runoff have become less correlated since the $1950 \mathrm{~s}$, probably due to the increasing anthropogenic disturbance. This occurred in the study catchment, where the similar annual precipitation produced less runoff in the 1990s than in the 1960s. Furthermore, there is a 


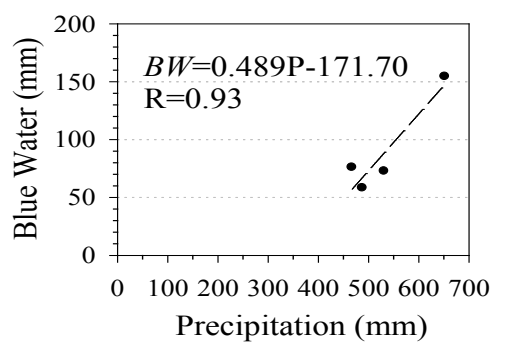

(a) $1950 \mathrm{~s}$

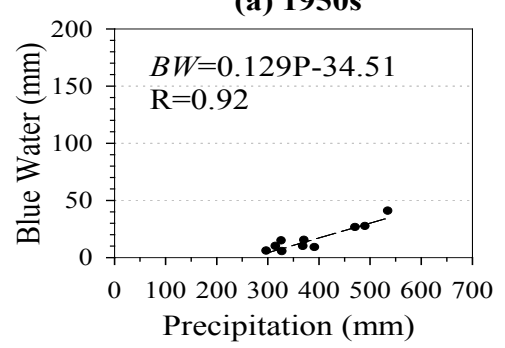

(d) $1980 \mathrm{~s}$

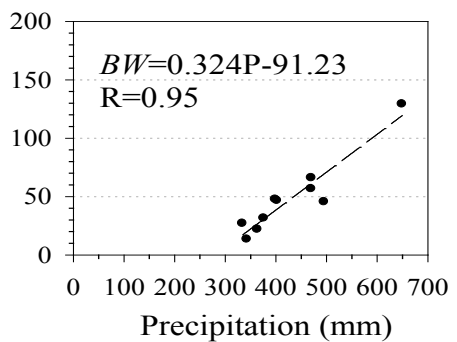

(b) $1960 \mathrm{~s}$

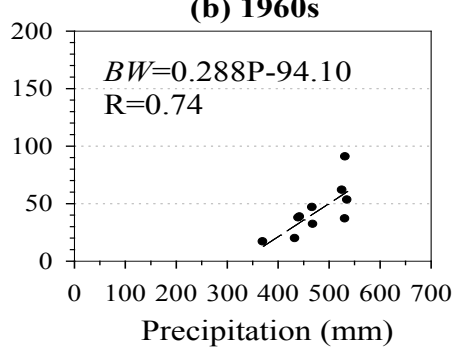

(e) $1990 \mathrm{~s}$

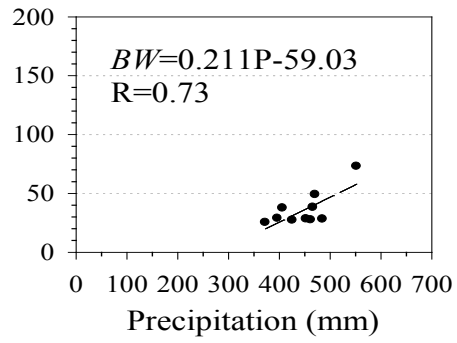

(c) $1970 \mathrm{~s}$

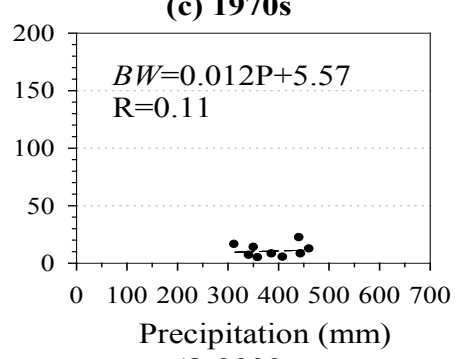

(f) $2000 \mathrm{~s}$

Fig. 1 Correlation between annual precipitation and runoff of the Laohahe catchment every 10 years.

negative correlation between annual precipitation and runoff over the Laohahe catchment in the 21 st century.

\begin{abstract}
ANALYSIS
The measured river runoff records were analysed for evidence of blue water change from the potential drivers. The business (Dooge 1986) or task (Bloeschl 2005) of hydrology is to solve the water balance equation, or the hydrological equation. As far as a catchment is concerned, the water balance equation on an annual or decadal scale can be expressed as $P-E T-R=\Delta W$, where $P$ is precipitation, $E T$ is evapotranspiration, and $R$ is runoff. $\Delta W$ refers to the water storage change in rivers, ponds, lakes, reservoirs, soil, rock, and other media within the area of a catchment during one year or 10 years. The above formula could be written as $P=G W+B W$, where evapotranspiration corresponds to green water $(G W)$ and runoff corresponds to blue water $(B W)$, if $\Delta W$ only changes slightly during one year or 10 years. On annual and longer temporal scales, $B W$ over a catchment is approximately equal to the difference between $P$ and $G W$. Figure 2(a) and (b) indicate that, in the last 50 years, the annual $P$ hardly changed, whereas $B W$ tended to decrease in the Laohahe catchment. From Table 1 and Fig. 2(c), the ratio of $G W$ (i.e. actual evapotranspiration) to precipitation increased in the past 50 years, i.e. $G W$ has represented an increasingly greater proportion of the precipitation since the 1950s. This can be explained by dividing both sides of the water balance equation by $P$ to derive $G W / P=1-B W / P$. The decrease of $B W / P$, or the so-called runoff coefficient, causes the increase of $G W / P$ in either one year or over a longer time scale. The annual potential evaporation, Fig. 2(d), has an evident decreasing tendency during the past half-century, whereas the mean annual temperature, Fig. 2(e), shows an increasing trend since the 1950s. The above result for the Laohahe catchment provides further support to the evaporation paradox (Brutsaert and Parlange 1998, Cong, et al. 2009) and the complementary relationship (Yang et al. 2006) regarding evaporation.

In general, two types of factors, climatic change and human activities, may result in runoff change. In the Laohahe catchment, many anthropogenic factors have the potential to affect green water flow, and thereby modify blue water. These include hydraulic structures built across rivers for disaster control, water supply and power generation, LUCC, agricultural irrigation, livestock breeding for meat production, water withdrawal from streams or river channels, and abstraction from underground aquifers for increasing municipal and industrial water demands, and even for paddy rice cultivation. Our decadal study, since 1999 under the National Key Basic Research Program of the Ministry of Science and Technology, China, has shown that the increase in water
\end{abstract}


withdrawal from streams and aquifers is the direct and predominant cause of blue water decrease in the Laohahe catchment. Figure 3 shows that the gross domestic product (GDP), population, agricultural products, and livestock in Chifeng, the main city within the Laohahe catchment, have increased tremendously since 1964. To meet the needs of the local economy and the livelihoods of people, more water is withdrawn and abstracted for population growth, agricultural irrigation, municipal operation, development of second and third industries, and industrial structure adjustment.

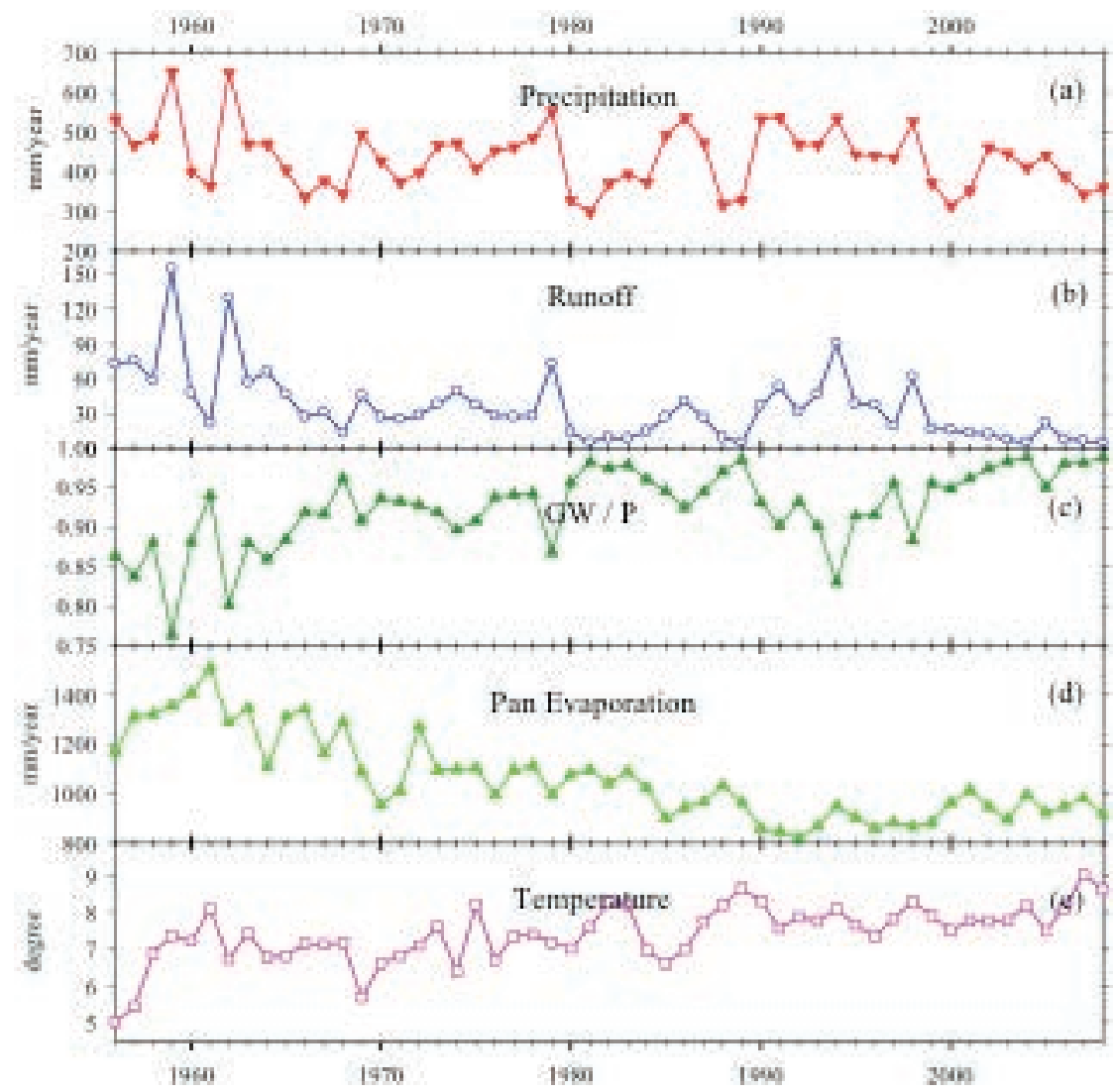

Fig. 2 Variations of annual precipitation, runoff, proportion of green water to precipitation, pan evaporation, and temperature over the Laohahe Catchment since 1956.

Table 1 Mean precipitation, runoff, pan evaporation and temperature of every decadal-year over the Laohahe catchment during the past half century.

\begin{tabular}{llllllll}
\hline Period & $\begin{array}{l}\text { Precipitation } \\
(\mathrm{mm})\end{array}$ & $\begin{array}{l}\text { Runoff } \\
(\mathrm{mm})\end{array}$ & $\begin{array}{l}\text { Runoff } \\
\text { coeff. }\end{array}$ & $\begin{array}{l}\text { GW } \\
(\mathrm{mm})\end{array}$ & $\begin{array}{l}\text { GW/ } \\
\text { Precipitation }\end{array}$ & $\begin{array}{l}\text { PET } \\
(\mathrm{mm})\end{array}$ & $\begin{array}{l}\text { Temperature } \\
(\text { degree })\end{array}$ \\
\hline $1956-1959$ & 535.1 & 90.2 & 0.17 & 444.9 & 0.83 & 1290.1 & 6.2 \\
$1960-1969$ & 430.4 & 48.4 & 0.11 & 382.0 & 0.89 & 1285.2 & 7.0 \\
$1970-1979$ & 449.4 & 36.1 & 0.08 & 413.3 & 0.92 & 1074.0 & 7.1 \\
$1980-1989$ & 390.6 & 16.0 & 0.04 & 374.6 & 0.96 & 1013.8 & 7.6 \\
$1990-1999$ & 475.4 & 43.0 & 0.09 & 432.4 & 0.91 & 874.2 & 7.9 \\
$2000-2008$ & 390.2 & 10.5 & 0.03 & 379.7 & 0.97 & 954.2 & 8.0 \\
\hline
\end{tabular}

Humans manipulate various landscape components: vegetation, soil, and water. Freshwater and ecosystem services cannot be provided without interfering with various landscape components, such as land and water pathways (Falkenmark and Rockström 2004). Evaporation from reservoirs and ponds causes the increase of green water. Population growth and livestock increase with the increase in drinking water amount, some of which becomes green water as well. Water consumed during food production evaporates and becomes green water that flows over the 

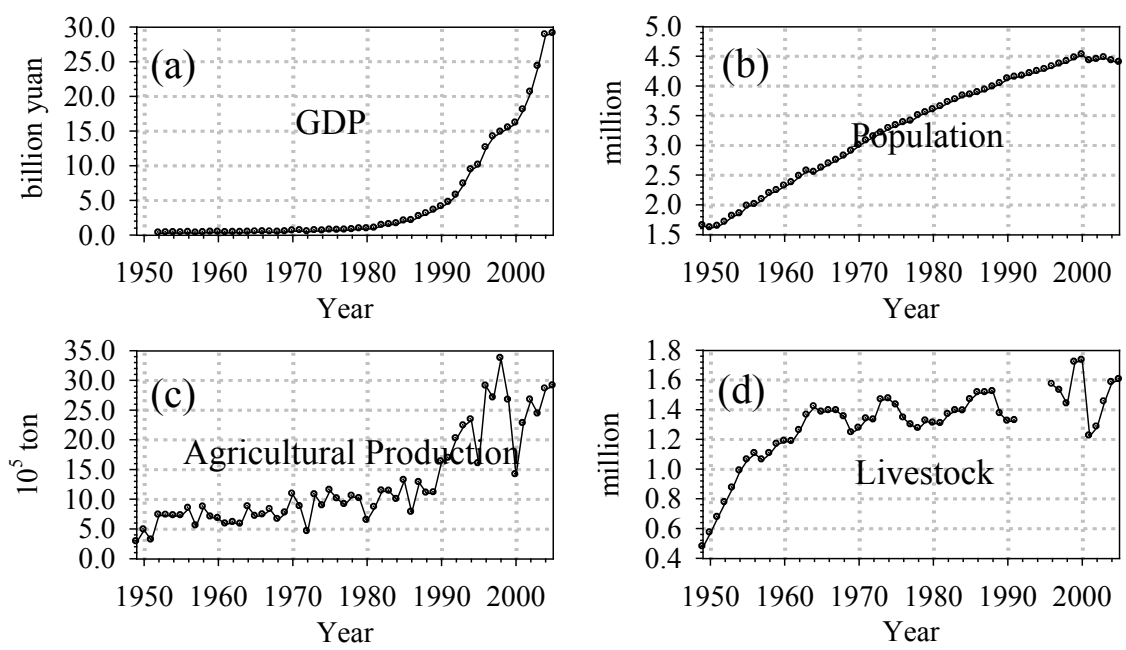

Fig. 3 Variations in GDP, population, agricultural products, and livestock in Chifeng, the main city within the Laohahe catchment, from 1949 to 2005

Laohahe catchment. More water also becomes green water when cropland (Yong et al. 2010) is irrigated by water abstracted from streams and wells. During two catchment surveys, in 2006 and 2008 , we found that underground water taken from wells was used for irrigation, even for paddy rice fields (see Fig. 4), in such a semi-arid catchment. In fact, more green water flow occurs in the paddy field than from grassland and forest land. These findings contribute to the increase of $G W$. Drilling wells and pumping groundwater for paddy land and other purposes will certainly lower the groundwater table, increase infiltration, and thereby reduce blue water. Water for agriculture occupied $76.3 \%$ of the total water usage in 2008 , according to the local statistics yearbook. To produce more food, water was withdrawn from streams and river channels, and pumped from wells for agricultural irrigation. Hence, more green water is released into the atmosphere over the catchment. Blue water, which should be generated in the downstream of the river, is converted into green water which remains and evaporates over the sloping farmland and plough-land surfaces in the upper and middle reaches of the catchment owing to human activities. The redirection of blue water into green water occurs in the Laohahe catchment.
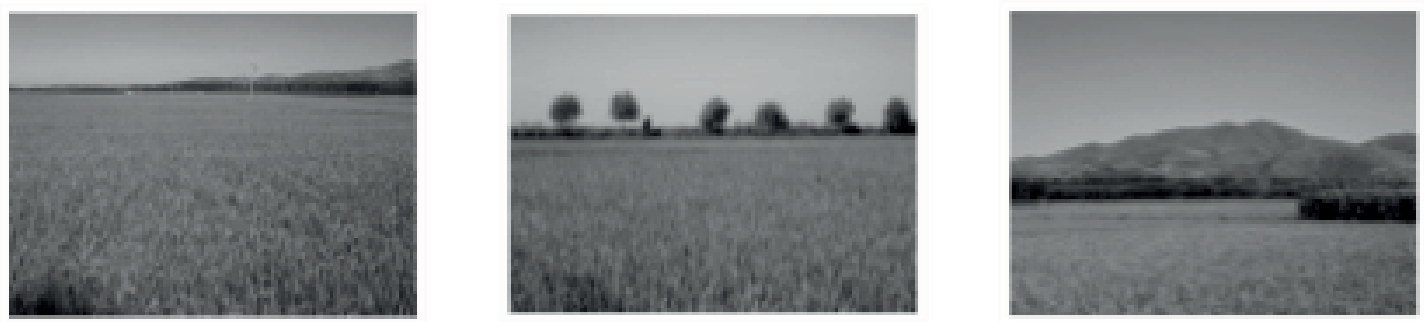

Fig. 4 Photos of paddy rice fields taken in situ during the investigation in August 2006 and 2008.

To investigate the inter-decadal change of blue water flow from the 1970 s to the 21 st century, a semi-distributed hydrological model coupled with a two-source potential evapotranspiration model for simulating catchment daily runoff was developed (Liu et al. 2009). The comparison of land-use data for 1980 with those in 1996 showed that forest land and cropland increased, whereas grassland and water body area decreased. This change led to an increase in the evaporation of canopy-intercepted water and vegetation transpiration, whereas evaporation from bare soil tended to decrease. The result of numerical experiments showed that LUCC could cause green water or ET to increase by $0.95 \%$, whereas blue water decreased by $8.71 \%$ in the Laohahe catchment (Liu et al. 2009). The computed value of the mean annual runoff depth (Liu et al. 2009) is $14.59 \mathrm{~mm}$ from 2000 to 2005, and the observed one (Liu et al. 2009) is $9.78 \mathrm{~mm}$ per year. The difference 
is $4.81 \mathrm{~mm}$ per year ( $49.2 \%$ of the observed). The flow direction of the blue water, amounting to $4.81 \mathrm{~mm}$ per annum in the $21 \mathrm{st}$ century, is still unknown. If $4.81 \mathrm{~mm}$ is multiplied by the area of the Laohahe catchment, $18112 \mathrm{~km}^{2}$, we obtain $8.712 \times 10^{7} \mathrm{~m}^{3}$ per annum. This value is equivalent to the amount of water stored in a certain scale of reservoir, and is very significant and helpful to local humans and nature. Man and nature influence precipitation partitioning into green and blue water from individual plants to river basins. An extreme illustration is that of Cherrapunji in India (Falkenmark and Rockström 2004), where local people suffer severe water scarcity. Deforestation and exposure of bare soil to intensive rainfall dramatically change the first partitioning point from a high proportion of soil infiltration to a dominance of storm surface-runoff flow. This flow has been completely redirected in favour of flash floods in streams. Perhaps the present blue water flow is not dissimilar to the volumes in past humid tropical landscapes with annual rainfall of over $10000 \mathrm{~mm}$. However, the flow duration has decreased from months to days. In the semi-arid region of northern China, the situation is slightly different from the above-mentioned case in India. River flows are generally decreasing, most of them as a result of water withdrawal from streams and endless abstraction from underground aquifers. The redirection of the blue water flow branch depends on the influence of human activities against a background of climatic change, including LUCC, increased livestock numbers for meat production, urbanization for the national economy and livelihood of people, and water management for increasing municipal and industrial water demands, especially due to irrigation for more food and agricultural products.

\section{DISCUSSION}

The case study over the Laohahe catchment provides a representative example of incompatible water usage in northern China. This leads to serious conflict between human interest and biomass production upstream in a catchment. The conflict will be particularly severe in this catchment with rapid population growth and escalating food needs. The redirection between green and blue water flows impels us to perform further research on water balance alterations linked to land-use change. The current study also confirms that a land-use decision is a decision about water usage (Falkenmark and Rockström 2004).

The influence of human activities on blue water is very complex in both the spatial and temporal scales. As land cover forms the boundary between the atmosphere and the terrestrial sphere, land-cover changes may have significant implications for water availability. By altering runoff pathways in catchments, the volume, timing, and quality of water flow can be affected. Human activities and hydrological processes are, therefore, linked through LUCC. But, the effects of human activity on hydrological regimes are not easy to predict quantitatively because they influence hydrology through the interactions among various hydrological processes, climatic elements, vegetation characteristics, site-specific circumstances, and management factors (Conway 2001). However, water withdrawal could be partly calculated, such as water transfer from reservoirs or canals. However, quantifying the effects of such human activities is still very difficult, because water usage increases due to land-use change, soil conservation, and socioeconomic structure modification. A methodology is needed to separate the influences of anthropogenic activities on water resources from the influences of climatic change on hydrological regimes. Although some progress have been made in this aspect (Yang et al. 2004, Jiang et al. 2011), a better modelling framework to effectively integrate climatic, hydrological, and agricultural models with social and economic analyses is still needed. Climate change should be closely related to land-use change.

Acknowledgements This work was financially supported by the National Key Basic Research Program of China (Grants G1999043404 and 2006CB400502), the National Key Technology R \& D Program (Grant 2013BAC10B02) and the Special Basic Research Fund for Methodology in Hydrology (Grant 2011IM011000) by the Ministry of Sciences and Technology, China, and the Innovative Research Team Project (Grant 2009585412) by the State Key Laboratory of Hydrology-Water Resources and Hydraulic Engineering. The authors also extend their 
appreciation for the support given by the 111 Project (Grant B08048) of the Ministry of Education and State Administration of Foreign Experts Affairs, China.

\section{REFERENCES}

Bloeschl, G. (2005) On the fundamentals of hydrological sciences. In: Encyclopaedia of Hydrological Sciences (ed. by Anderson, M. G.), 3-12. John Wiley \& Sons Ltd, England.

Brutsaert, W. and Parlange, M. B. (1998) Hydrologic cycle explains the evaporation paradox. Nature 396,29 - 30.

Cong, Z. T., Yang, D. W. and Ni, G. H. (2009) Does the evaporation paradox exist in China? Hydrol. Earth Syst. Sci. 13, $357-366$.

Conway, D. (2001) Understanding the hydrological impacts of land-cover and land-use changes. Newsletter of the IHDP on Global Environmental Change, http://www.uni-bonn.de/ihdp/update.htm

Dooge, J. C. I. (1986) Looking for hydrologic laws. Water Resources Research 22, 465-585.

Falkenmark, M. and Rockström, J. (2004) Balancing Water for Humans and Nature - The New Approach in Ecohydrology. Earthscan, London.

Fu, C. and Penning de Vries, F. (2007) Initial Science Plan of the Monsoon Asia Integrated Regional Study. Meteorology Press, Beijing.

Gedney, N., et al. (2006) Detection of a direct carbon dioxide effect in continental river runoff records. Nature 439, 835-838.

Jiang, S., et al. (2011) Quantifying the effects of climate variability and human activities on runoff from the Laohahe basin in northern China using three different methods. Hydrol. Processes 25, 2492-2505.

Labat, D., et al. (2004) Evidence for global runoff increase related to climate warming. Adv. Water Res. 27, 631-642.

Liu, X., et al. (2009) Quantifying the effect of land use and land cover changes on green water and blue water in northern part of China. Hydrol. Earth Syst. Sci. 13, 735-747.

Probst, J. L. and Tardy, Y. (1987) Long range stream-flow and world continental runoff fluctuations since the beginning of this century. J. Hydrol. 94, 289-311.

Ren, L., et al. (2002) Impacts of human activity on river runoff in the northern area of China. J. Hydrol. 261, $204-217$.

Shiklomanov, I. A. (2000) Appraisal and assessment of world water resources. Water Int. 25, 11-32.

Wang, H., et al. (2010) Subject system of modern hydrology and water resources and research frontiers and hot issues. Adv. Water Sci. 21(4), 479-489 (in Chinese).

Yang, D., et al. (2004) Analysis of water resources variability in the Yellow River of China during the last half century using historical data. Water Resources Research 40(6), W06502, doi:10.1029/2003WR002763.

Yang, D., et al. (2006) Interpreting the complementary relationship in non-humid environments based on the Budyko and Penman hypotheses. Geophys. Res. Lett. 33, doi:10.1029/2006GL027657.

Yong, B., et al. (2010) Hydrologic evaluation of Multisatellite Precipitation Analysis standard precipitation products in basins beyond its inclined latitude band: A case study in Laohahe basin, China. Water Resources Research 46, doi:10.1029/2009WR008965. 